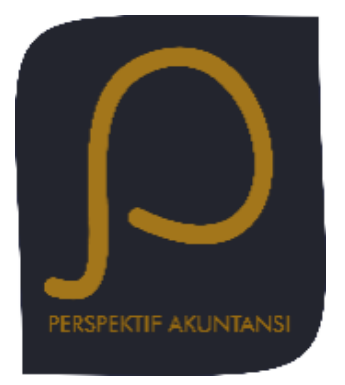

Perspektif Akuntansi

Volume 3 Nomor 2 (Juni 2020), hal. 155-166

ISSN: 2623-0194 (Print), 2623-0186 (Online)

Copyright $(\subset)$ The Authors(s). All Rights Reserved

Fakultas Ekonomika dan Bisnis,

Universitas Kristen Satya Wacana

DOI: https://doi.org/10.24246/persi.vXiX.p155-166

http://ejournal.uksw.edu/persi

\title{
Profitability, Liquidity, Leverage and Firm Size on Dividend Payment
}

\author{
Farah Chintya Benyadi \\ President University \\ Hajanirina Andrianantenaina ${ }^{1}$ \\ President University
}

Received

$17 / 04 / 2020$

Abstract. This research aims to test whether dividend payment is affected by profitability, liquidity, leverage and firm size. This

Accepted $30 / 06 / 2020$ study uses logistic regression to analyse manufacturing companies, listed on Indonesia Stock Exchange. These manufacturing firms are selected as sample for 2013 to 2017 period. The result of this study showed that profitability and firm size has significantly associated with dividend payment, while liquidity and leverage has not significantly associated with dividend payment. It could help investors to consider firm asset tangibility and its effectiveness to earn profit while deciding to invest in a manufacturing company.

Keywords: dividend payment, profitability, liquidity, leverage, firm size

\begin{abstract}
Abstrak. Penelitian ini bertujuan untuk menguji apakah pembayaran dividen dapat di pengaruhi oleh profitabilitas, likuiditas, leverage dan ukuran perusahaan. Penelitian ini menggunakan regresi logistik untuk menganalisis perusahaan manufaktur yang terdaftar di Bursa Efek Indonesia. Perusahaan manufaktur diambil sebagai sampel selama periode pengamatan 2013 sd 2017. Hasil dari penelitian ini menunjukkan bahwa
\end{abstract}

${ }^{1}$ hajanirina@president.ac.id 
profitabilitas dan ukuran perusahaan mempengaruhi kebijakan dividen sedangkan likuiditas dan leverage tidak mempengaruhi kebijakan dividen. Hasil ini dapat membantu investor untuk mempertimbangkan tangibilitas aset perusahaan dan keefektivannya untuk memperoleh laba pada saat memutuskan untuk berinvestasi pada perusahaan manufaktur.

Kata kunci: kebijakan dividen, profitabilitas, likuiditas, leverage, ukuran perusahaan

\section{Introduction}

In the globalization era, there is the competitiveness of economics in most fields of business activities, whether adding the value of shareholder wealth or fulfill the customer satisfaction with quality but competitive price product (Kumar \& Chandrasekar, 2014). With the growth of economy in Indonesian, many investors' are attracted to invest their wealth with buying shares to obtain return in capital gain and dividend (Muda, 2017). Investors who expect more in dividend usually put attention in the dividend payment of the company which determine the proportion of the company's profit that going to be distributed to shareholder and profit that will be reinvest by the company (Ahmad \& Wardani, 2014). Dividend payment is one of essential factor that management should give more attention since dividend payment has significant influence not only for external side but also internal side. Dividend payment could affect the opportunities of new investment for the company, the financial structure, the stock price, the flow of funding and the liquidity position (Nurmala, 2009). Although, not few are the researches on dividend payment, previous results require again research on the impact of how the firm manage the asset regarding its size as we search in this paper. It is necessary for the case of Indonesia as the majority of the economic driven business units are from SMEs (UMKM). However, large firms attract more investors.

Dividend payment has been a concern and contentious issue in the corporate finance literature, initiated by Lintner (1956) classic work with the discussion on dividend. There are uncountable research that has been discussed about dividend payment and various theory such as signaling theory, agency cost theory, bird in the hand theory and the dividend irrelevance, have been emerged to answer the different questions relating to dividend payment (Kannadhasan et al., 2017). There are several factors from both internal side and external side that could affects dividend payment. In their research, La Porta et al (1998) stated that the dividend payment could affect by internal factors such as liquidity, profitability and investment opportunities. DeAngelo et al. (2006) found that there is highly significant relation between the dividend payment with the ratio of earned equity to total equity or total assets, controlling for firm size, profitability, growth, leverage, cash balance and dividend history. Roy (2015) presented that the firm 
liquidity that used proportion of cash and cash equivalent to total asset as measurement, have significant impact on the dividend payment, while growth opportunity has a positive impact on the dividend payment. In the other side, Ahmad and Wardani (2014) investigating the effect of fundamental factors to dividend payment in Indonesia stock exchange observe that profitability and firm size correlates significantly positive with dividend payment, liquidity and leverage correlates negative significantly with dividend payment while growth opportunities do not significantly correlated with dividend payment; but simultaneously all the variables correlated significantly with dividend0policy. The research conduct by Kaźmierska-Jóźwiak (2015) in Polish Listed Companies stated that there is negative relationship between profitability and leverage with dividend payout ratio, while in the research by Pinem and Dwi (2016) stated that return of equity, sales growth and return on assets simultaneously affect the dividend payment but partially, variables sales growth and return on assets has negative affect with dividend0policy, while the return on equity has no effect on dividend payment.

As based on these empirical studies, this research tries to analyze the factors that related to dividend payment. Although research related to dividend payment is a concern that has been long and wide studied in financial literature, but the results of that are still inconsistent. This study uses size of the company to estimate the management of the comapny wealth towards dividend policiy. It is often viewed as younger companies tend to focus on growth (not dividend) whereas well established firms attract investors through paying dividend. In this research, we then focus on how firm size impacts on dividend policy. Related to the use of asset, ROA is added to support this argument. Therefore the researcher interested in studying about the dividend payment and tries to find the relationship between profitability, liquidity, leverage, and firm size to dividend payment.

\section{Literature review}

\section{Profitability and Dividend Payment}

Tamrin et al, (2017) found that profitability determined significantly the dividend policy of the firm. The result showed that a firm with an increase of the profitability tended to manage the dividend payment by optimizing the income. Yet, the result showed negative relationship, in this study, we follow Aivazian et al. (2003) since, the higher the firm the profit it earns, the more likely it will componsate the shareholders by payind dividend.

Dividend payment consist of how the firm compensates its shareholders through paying dividend, either using cash, stock, or other alternatives. Firm tends to pay dividend in line with the current conditions regarding its 
profitability, the share availability, the income of the previous and current year. Paying dividend becomes an attractive decision to enhanve investor's trust towards the management in short and long term.

Dividends are paid by management to shareholder using profit of the company, so it is almost impossible for an unprofitable company to always depend from past retained profit to paying dividend. According to Lintner (1956), a firm's net earnings are an important factor influencing dividend payments. Similarly, the pecking order theory states considering the cost of debt and equity, low profit company will not consider as ideal to pay dividend, while high profitable company will have greaterability to pay dividends.

The study conducted by Aivazian et al. (2003) shows that dividend payout ratio is positively related to profitability and return on equity, while according to Fama and French (2001), dividend decisions are influenced by firm size, profitability and investment opportunities. They argued that a company's likelihood to pay dividends are positively associated to profitability and size but adversely to growth that is, unlike companies with investment opportunities, large companies are more lucrative and tend to pay dividends.

On the contrary, in the study conducted by Kaźmierska-Jóźwiak (2015) in Polish listed company, the profitability of the company has significant negative relationship with the dividend payment. It means that the company are using the retained earning as capital sources and less likely to pay dividend. Likewise, Pinem and Dwi (2016) stated in their study that return on asset has negative effect on the dividend payment, while the return on equity has no effect on dividend payment. They stated that greater the company assets comes with the greater the need for the necessary funds to finance the company, so that distributed dividend tends to become lower. They also informed that the shareholders does not consider the distributed profit use decision and the company's own capital in the investment decision-making, namely the decisions on the dividend payments.

Based on these evidences, the hypothesis is as follows:

$\mathrm{H}_{1}$ : Profitability has positive relationship to dividend payment

\section{Liquidity and Dividend payment}

Liquidity is a one of important factor in determining dividend payment. Poor liquidity position will result in shortage of cash and hence fewer dividends. According to Ho (2003), dividend policies are positively influenced by size and liquidity in Australia and Japan respectively. Hence, according to 
Alli et al. (1993), dividend is more dependent on a company's cash flows that provide the capacity of the company in pay dividends rather than current earnings which can be easily manipulated through accounting. This was supported by Brook et al. (1998) where companies which were expecting large augmentation in permanent cash flow raised their dividend. However, in Myers and Bacon (2001) study, they indicate that the liquid ratio and dividend payout are negatively correlated. Similarly, Ahmad and Wardani (2014) also stated in their study that there is negative significant between liquidity and dividend payment. It is so as the more liquid the company while it is in take off or growing level, the company tends to invest not to pay dividend. However, we follow, the adverse opinion as in Barros et al. (2020), as the firm we consider are large firms. Thus, positive relationship is expected as firms with higher liquidity tend to pay more dividend while the short terms are considered (level of cash).

$\mathrm{H}_{2}$ : Liquidity has positive relationship to dividend payment

\section{Leverage and Dividend payment}

According to Syamsudin (2011), leverage is the ability of the company to use fixed assets or asset and funds that have fixed cost to increase the level of the company. A relationship between leverage and dividend payment is expected from the trade-off theory state by Modigliani and Miller and pecking order theory proposed by Myers and Majluf (Trang, 2012). According to Modigliani and Miller (1961), the increase of debt level could be taken as great signal for the company's future earning and will increase the company value that will be impact to the firm willing in paying higher dividends. The debt that increasing also could motivate management to work efficiently because of the fewer benefit for themselves. In other hand, Ahmad and Wardani (2014) show the negative and significant relationship between leverage and dividend payment. Likewise, Naceur et al. (2005) also stated in their study that company's with high debt levels tend to pay dividend in low quantity and has a low dividend yield.

$\mathrm{H}_{3}$ : Leverage has negative relationship to dividend payment

\section{Firm Size and Dividend payment}

For Barros et al. (2020), larger firms are able to pay dividend. When a firm is stable on growth and has bigger asset, manager tends to focus on how to componsate the shareholder. According to Machfoedz (1999), the size of a company could be divided into three different classes, which are large firm, 
medium firm and small firm. Firm size usually measured by total asset of a company, since the total asset could show the ability of a company in operating their business. Medium or smaller firm tends to have fewer shareholders compare with larger firm because smaller firm usually used their profit to financing their operation or raising their business, while the larger firm tends to hold the trust of the shareholder by share the profit of the business with dividend. According to the research by Ranti (2013), there is positive association between firm size and the dividend payout of firm listed in Nigeria. The research also observed that firm size is also a strong determinant of firms' dividend payout decision; since the larger firms typically have easier and better access to market capital in order to raise the funds.

$\mathrm{H}_{4}$ : Firm size has positive relationship to dividend payment.

\section{Method}

\section{Data and samples}

This research uses secondary data. The data are fetched from Indonesia Stock Exchange and/or directly from the company official sites. It analyses the evidence on these companies for five years (2013 - 2017).

Sampling method

The reason of using manufacturing sector as a sample is because the manufacturing sector is a big sector which consist of many company that actively listed and paying their dividend anually. The criterias applied in this research are:

- Manufacturing sector companies that still actively listed on the Index companies for the period of analysis.

- Manufacturing sector companies that constintently listed on the Index companies for the period of analysis.

- The companies use rupiah (IDR) for financial reporting for the period of analysis.

- The companies which has annual report for the period of analysis.

- The companies present the financial statements in accordance with the variables used in this research.

Sample in this research are

Sampling 
Tabel 1. Sampling procedure

\begin{tabular}{cc}
\hline Sample Descriptions & The Number of Companies \\
\hline $\begin{array}{c}\text { The manufacturing companies listed on } \\
\text { Indonesia Stock Exchange }\end{array}$ & 168 \\
The manufacturing companies consistently listed \\
on Indonesia Stock Exchange (IDX) $2013-2017$ \\
The manufacturing companies actively listed on \\
Indonesia Stock Exchange (IDX) 2013 - 2017 \\
Companies that0do not use rupiah currency \\
Unavailable annual report \\
Incomplete Data \\
Selected companies for the sample
\end{tabular}

\section{Research model}

Binary Logistic Regression (BLR) model is used for this research to measure the dichotomous dependent variable. This logistic model is using cumulative distribution function which is a principal to represent that a model could show the response of dependent variable with two scale categories, 1 if the company pays dividend and 0 elswhere.

Thus, the logistic regression equation model as follows:

$$
D I V_{i}=\beta_{0}+\beta_{1} R O A_{i}+\beta_{2} C R_{i}+\beta_{3} L E V_{i}+\beta_{4} S I Z E_{i}+\varepsilon_{i}
$$

Where:

DIV: dividend payment, with dummy variable, 1 if the company pays dividend and 0 elswhere.

ROA: Return on Asset, return on asset is the ratio from earning after tax to average total asset

CR: Current Ratio, is the ratio from current asset to current liability

LEV: Financial Leverage, is derived from the ratio of total debt to total asset

SIZE: firm size, is the ln of total asset.

$\varepsilon: \quad$ the residual

\section{Result and discussion}




\section{Result}

\section{Descriptive statistics}

Tabel 2. Descriptive Statistics

\begin{tabular}{llllll}
\hline & $\mathrm{N}$ & Minimum & Maximum & Mean & Std. Deviation \\
\hline DIV & 299 & 0.000000 & 1.000000 & 0.511706 & 0.500701 \\
ROA & 299 & -1.617225 & 1.444496 & 0.069398 & 0.202290 \\
CR & 299 & 0.132725 & 13.87127 & 2.374824 & 2.153851 \\
LEV & 299 & 0.025249 & 9.410670 & 0.605803 & 0.843544 \\
SIZE & 299 & 11.40006 & 18.33547 & 14.43220 & 1.543887 \\
\hline
\end{tabular}

Source: Data Processed (2019)

In 2016, Jembo Cable Company Tbk (JECC) has the minimum value of CR with 0.132725 , showing that the liquidity of the company is only $13.27 \%$. As liquidity is the ratio from current asset to current liability, thus its current asset is 0.1327 times its current liability. In other hand, the maximum value is owned by Intanwijaya Internasional Tbk (INCI) in periods of 2013 with 13.87127 , presented the high liquidity of the company that year. As can be seen in table 4.2, the minimum value of the LEV is owned by Gunawan Dianjaya Steel Tbk (GDST) in 2013 with 0.025249 while the maximum value is owned by Tirta Mahakam Resources Tbk (TIRT) in 2014 with 9.410670 . The lower value of leverage indicates that the company has a better ability to pay its long-term obligations, and vice versa. Last, firm size minimum value is owned by Primarindo Asia Infrastructure Tbk.(BIMA) in 2017 with 11.40006 and the maximum value is owned by Indofood Sukses Makmur Tbk (INDF) in 2015 with 18.33547. The higher value of firm size indicates the size of the company by using their total asset that year.

\section{Hypothesis testing result}

Tabel 3. Regression result

\begin{tabular}{crrrr}
\hline Variable & Coefficient & Std. Error & z-Statistic & Prob. \\
\hline C & -12.86313 & 2.201337 & -5.843325 & 0.0000 \\
ROA & 23.01877 & 3.242775 & 7.098480 & 0.0000 \\
CR & 0.018780 & 0.084784 & 0.221504 & 0.8247 \\
LEV & -0.077831 & 0.202834 & -0.383720 & 0.7012 \\
SIZE & 0.811334 & 0.148184 & 5.475198 & 0.0000 \\
\hline
\end{tabular}

McFadden R-squared 0.452902

Source: Data Processed (2019) 
Based on Table 3, ROA and firm size positevely and significantly impact on the dividend payment. On the contrary, CR and LEV do not. Thus, the first and fourth hypotheses are supported while the second and third are not with the level of $5 \%$.

\section{Discussion}

\section{Profitability and dividend payment}

Company with high profitability tends to pay dividend to shareholder in order to maintain the shareholder and invites new shareholder to invest in their company. Investor usually expected dividend while investing in a company, therefore the company with high profitability will used the chance to invites new shareholder. This result was supported by Ahmad and Wardani (2014) research that profitability has significance influence towards dividend payment.

\section{Liquidity towards Dividend payment}

Liquid company is supposed to be able to pay-off their short term debt using their liquid asset. However, even when the company is high liquid, it does not mean that the company will pay the dividend because the asset could be used to pay the long-term debt, maximize their operational or continuing to next year books because the loss in previous years. The result is supported by Myers and Bacon (2001) that stated in their study that liquidity ratio has no significance relation with dividend payment.

\section{Leverage towards Dividend payment}

Even though this ratio could affect the decision of investor in making investment to a company; this ratio is not strong enough to influence the dividend payment. Even if the company is able to paying off their long-term debt, it did not mean the company will paying the dividend that year because the company could be focused using their current asset or profit to pay-off their short term debt and decide not to pay the dividend. The result of this study supported by Naceur et al. (2005) also stated in their study0that companies with leverage ratio did not has significance relation with dividend payment.

\section{Firm Size towards Dividend payment}

Large company tends to enter the market capital easily and invites the investor to invest in their company by paying the dividend. Investor will expected more in a company that paying the dividend compare than the 
company who does not paying the dividend annually. Therefore, the larger company's management decision tends to pay the dividend compare with the smaller company, shows that there is significant influence between firm size and dividend payment. This result is supported by Ahmad and Wardani (2014) in their study that firm size has significant influence towards dividend payment.

\section{Conclusion}

This research finds that firm size and profitability are important variables to explain the manufacturing firms as used to decide on the dividend payment. Positive relationship implies the magnitude of the firm effectiveness and asset intangibility while considering to pay dividend or not. Contrarily, being liquid whith leverage could not explain the phenomena on the matter of dividend. Thus, it could help the company to mange the asset for its operating, financing and investing activity. Investors could consider the firm size and the effectiveness on the asset management but not only focus on the liquidity (especially for short term). This research might lacks on the longitudinal process for the analysis. It is advisable as well the ownership influnces on dividend payment because the shareholders can have final decision considering divend as well. Future research might consider the use of merger and acquisition on paying dividend as it might enhance the investor attention to the company.

\section{References}

Ahmad, G. N., \& Wardani, V. K. (2014). The Effect of Fundamental Factor to Dividend payment: Evidence in Indonesia Stock Exchange. International Journal of Business and Commerce, 4(2), 14-25.

Aivazian, V., Booth, L., \& Cleary, S. (2003). Do Emerging Market Firms Follow Different Dividend Policies From U.S. Firms? Journal of Financial Research, 26(3), 371387.

Alli, K. L., Khan, A. Q., \& Ramirez, G. G. (1993). Determinants of Corporate Dividend payment: A Factorial Analysis. The Financial Review, 28(4), 523-547.

Boujelbene, Y., \& Besbes, L. (2012). The Determinants of Information Asymmetry between Managers and Investors: A Study on Panel Data. IBIMA Business Review, 2012(2012), 1-11.

Brook, Y., Charlton, W. T., \& Hendershott , R. J. (1998). Do Firms Use Dividends to Signal Large Future Cash Flow Increases? Financial Management, 27(3), 46-57.

Dadbeh, F., \& Mogharebi, N. (2013). A Study on Effect of Information Asymmetry on Earning Management: Evidence from Tehran Stock Exchange. Management Science Letters, 3(7), 2161-2166.

DeAngelo, H., DeAngelo, L., \& Stulz, R. M. (2006). Dividend payment and The Earned or Contributed Capital Mix: a Test of The Life-Cycle Theory. Journal of Financial Economics, 81(2), 227-254. 
Deshmukh, S. (2005). The Effect of Asymmetric Information on Dividend payment. Quarterly Journal of Business and Economics, 44(1/2), 107-127.

Durrah, O., Rahman, A. A., Jamil, S. A., \& Ghafeer, N. A. (2016). Exploring the Relationship between Liquidity Ratios and Indicators of Financial Performance : An Analysis Study on Food Industrial Companies Listed in Amman Bursa. International Journal of Economic and Financial Issues, 6(2), 435-441.

Easterbrook, F. H. (1984). Two Agency-Cost Explanations of Dividends. American Economic Review, 74(4), 650-659.

Fama, E. F., \& French, K. R. (2001). Disappearing Dividends: Changing Firm Characteristic or Lower Propensity to Pay? Journal of Financial Economics, 60(1), 3-43.

Griffin, P. A. (1976). Competitive Information in The Stock Market: An Empirical Study of Earnings, Dividens and Analyst' Forecasts. Journal of Finance, 31(2), 631-650.

Gupta, V. (2017). Factors Determining the Dividend payment of a Company. Abhigyan, 35(3), 21-30.

Ho, H. (2003). Dividend policies in Australia and Japan. International Advances in Economic Research, 9(2), 91-100.

Jensen, M. C., \& Meckling, W. H. (1976). Theory of the Firm: Managerial Behavior, Agency Costs and Ownership Structure. Journal of Financial Economics, 3(4), 305-360.

Kannadhasan, M., Aramvalarthan, S., Balasubramanian, P., \& Gopika, A. (2017). Determinants of Dividend payment of Indian Manufacturing Companies: Panel Autoregressive Distributed Log Analysis. Academy of Accounting and Financial Studies Journal, 21(2), 1-12.

Kaźmierska-Jóźwiak, B. (2015). Determinants of Dividend payment: Evidence from Polish Listed. Procedia Economics and Finance, 23(1), 473-477.

Khang, K., \& King, T.-h. D. (2006). Does Dividend payment Relate to Cross-Sectional Variation in Information Asymmetry? Evidence from Return to Insider Trades. Financial Management, 35(4), 71-94.

Kumar, D., \& Chandrasekar, V. (2014). Financial Management Analysis of Dividend payment Pursued by Selected Indian Manufacturing Company. Journal of Financial Management and Analysis, 27(1), 20-32.

La Porta, R., Lopez-de-Silanes, F., Shleifer, A., \& Vishny, R. W. (1998). Law and Finance. Journal of Political Economy, 106(6), 1113-1155.

Li, K., \& Zhao, X. (2008). Asymmetric Information and Dividend payment. Financial Management, 37(4), 673-694.

Lin, T.-J., Chen, Y.-P., \& Tsai, H.-F. (2017). The Relationship Among Information Asymmetry, Dividend payment and Ownership Structure. Finance Research Letters, 20(1), 1-12.

Lintner, J. (1956). Distribution of Income of Corporations Among Dividend, Retained Earning, and Taxes. American Economic Review,46(2), 97-113.

Masdupi, E. (2005). Analisis Dampak Struktur Kepemilikan pada Kebijakan Hutang dalam Mengontrol Konflik Keagenan. Jurnal Ekonomi dan Bisnis Indonesia 2005, XX(I).

Mehta, A. (2012). An Empirical Analysis of Determinants of Dividend payment - Evidence from the UAE Companies. Global Review of Accounting and Finance, 3(1), 1831.

Miller, M. H., \& Rock, K. (1985). Dividend payment under Asymmetric Information. The Journal of Finance, 4(4), 1031-1051.

Modigliani, F., \& Miller, M. H. (1961). Dividend payment, Growth, and The Valuation of Shares. Journal of Business, 34(4), 411-433.

Muda, I. (2017). Role of Dividend of Power to Buy Shares in Companies in Indonesia Stock Exchange. Academic Journal of Economic Studies, 3(2), 41-47. 
Myers, M., \& Bacon, F. (2004). The Determinants of Corporate Dividend payment. Academy of Accounting and Financial Studies Journal, 8(3), 17-28.

Nurchaqiqi, R., \& Suryani, T. (2018). The Effect of Leverage and Liquidity on Cash Dividend payment with Profitability as Moderator Moderating . Accounting Analysis Journal, 7(1), 10-16.

Nurmala. (2009). Effect of Dividend payment On Stock Price Automotive Enterprises in the Jakarta Stock Exchange. Independent Vol. 9 No. 1, 34-47.

Pinem, D., \& Dwi , B. (2016). The Analysis of Company Performance and Sales Growth to the Dividend payment at the Company Go Public In Indonesia Stock Exchange. International Journal of Business and Commerce, 5(6), 105-116.

Rosadi, D. (2011). Analisis Ekonometrika dan Runtun Waktu Terapan dengan R. Yogyakarta: Andi Offset.

Roy, A. (2015). Dividend payment, Ownership Structure and Corporate Governance: An Empirical Analysis of Indian Firms. Indian Journal of Corporate Governance, 8(1), 1-33.

Rozeff, M. S. (1982). Growth, Beta and Agency Costs as Determinants of Dividend Payout Ratio. The Journal of Financial Research, 5(3), 249-259.

Sartono, A. (2008). Manajemen Keuangan Teori dan Aplikasi Edisi Empat. Yogyakarta: BPFE.

Sugiyarso, G., \& Winarni, F. (2005). Manajemen Keuangan. Yogyakarta: Media Pressindo.

Sugiyono. (2009). Metode Penelitian Kuantitatif, Kualitatif dan R\&D. Bandung: Alfabeta.

Syamsudin, L. (2011). Manajemen Keuangan Perusahaan. Jakarta: Raja Grafindo Persada.

Trang, N. X. (2012). Determinants of Dividend payment: The Case of Vietnam. International Journal of Business, Economics and Law, 1(1), 1-18. 